\title{
The Dynamics of Sunni and Shia Relationship: Majority and Minority Conflicts, in Psychological Perspective
}

\author{
$1^{\text {st }}$ Dini Permana Sari ${ }^{1}, 2^{\text {nd }}$ Yuminah $^{2}, 3^{\text {rd }}$ Benny Herlena $^{1}$ \\ \{dini_permana18@mhs.uinjkt.ac.id ${ }^{1}$, yuminah@uinjkt.ac.id ${ }^{1}$, bennyherlena@uin.suka.ac.id ${ }^{1}$ \} \\ UIN Syarif Hidayatullah, Islamic Studies Department ${ }^{1}$, UIN Syarif Hidayatullah, Faculty of Education ${ }^{2}$
}

\begin{abstract}
The dynamics of Sunni and Shia relations in Indonesia show that there are several conflicts and even acts of violence, including conflicts in Sampang, Madura (2011-2012) and community conflicts with IJABI (Indonesian Ahlul Ba'it Association) in Bondowoso (2017) and the emergence of a movement The Anti-Shi'a National Alliance (ANNAS) in West Java. The relationship of Sunni and Shi'ite disharmony in the world is also shown by conflicts in Middle Eastern countries. This article analyzed the relation of Sunni-Shia on periode 2008 to 2018 in Indonesia. The possibility to continue to conflict or unite becomes a dynamic relationship between them. By knowing the psychological condition between Sunni and Shia, it is hoped that mutual understanding will emerge between the two parties.
\end{abstract}

Keywords: Relationship, Sunni, Shia, Conflict, Majority, Minority, Psychology Perspective.

\section{Introduction}

At the time of the Prophet, Islam was a perfect religion, where there were no differences in understanding or interpretation in the teachings (aqeedah and fiqh). The division of Islam into Sunni and Shia, occurred in the period after the death of Rasulullah SAW, precisely at the time of the Caliph Ali RA, due to the Mu'awiyah rebellion in 37 Hijriyah [1].

Starting from the split then accompanied by the development of theological thought, the more visible differences in interpretation or interpretation in Islamic teachings, both in aqeedah and fiqh $[2,3]$. With these differences, it affects the lives of Muslims socially and culturally, both in Indonesia and in the world. This difference creates a conflict between the two, both in Indonesia and in the Middle East [4-8].

The Sunni and Shiite conflict in Indonesia is reflected in the case of the expulsion of Shiites in Sampang-Madura. Then came the anti IJABI movement in Bondowoso and the ANNAS movement in Bandung [1].

With this background, the author of this paper will present a brief history of the 
emergence of Sunni and Shiite, differences and similarities of Sunni-Shiite, its development in the Middle East and in Indonesia, especially in Java and a review of psychological dynamics between them (as majority and minority). By understanding this, we can find out the position or dynamics of the relationship between the parties and how we as Muslims behave.

\section{Understanding and A Short History of Sunni}

The term Sunni or ahlus sunnah wal Jama'ah or As-Sunnah, is etymologically derived from the word "sanna" which means to flow and stay away. The word "sunnah" means sirah or tariq (history and travel) [9]. Meanwhile, according to Nawir Yuslem, explaining that the terminological meaning of sunnah is any that is received from the Prophet or what is left from the Prophet Muhammad, whether in the form of words, deeds, his approval which is physical or moral, or life, either before he was appointed as an Apostle or after the apostles of the Prophet Muhammad SAW [10].

Quraish Shihab explains that Sunnah literally means tradition, Ahl ash-Sunnah in terminology means a person or group of people who consistently follow the traditions of the Prophet Muhammad, in oral guidance, practices of the Prophet and his companions of the Prophet Muhammad. But Quraish Shihab does not explain which groups are called Ahlussunnah in terms of the terminology, this is because there are many groups that feel included in Ahlussunnah [33]

Siradjuddin Abbas explained the meaning of Ahlussunah is the follower of the Sunnah of the Prophet, and the meaning of wal Jama'ah is the follower of I'tiqad as I'tiqad congregation of friends of the Prophet Muhammad SAW. So that the people of Ahlussunnah wal Jama'ah are the people who adhere to the I'tiqod who are embraced by the Prophet and his friends [32]. Based on some of the opinions mentioned above, it can be concluded that the definition of Sunni or Ahlus Sunnah Wal Jama'ah is a group or group of people (jama'ah), who consistently follow the faith, guidance of the Prophet, both oral and deed (deeds) of the Prophet and the

Companions of the Prophet Muhammad SAW.

In the historical view of Islamic theology shows that the birth of Ahlussunnah Wal Jama'ah was born in reaction to the emergence of the Mu'tazilah ideology known by its character, Washil bin 'Atho. The groups that emerged after the Mu'tazilah understood were the Asy'ariah and Maturidyah groups as opposed to the minority and not strong Mu'tazilah group holding the Sunnah. Both of these groups are included in the group Ahlussunnah Wal Jama'ah as the majority group that holds strongly to the sunnah [34]. Quraish Shihab explained that one of the writings of a letter from Salim al-Bisyri (Shaykh al-Azhar) to Abdul Husain Syarafuddin Al Musawi (Shi'ite figure) stated that his understanding of Ahlussunah was the largest group of Muslims who followed the Ash'ari sect in matters of faith and in Sharia affairs, following the four Imams of the School, namely: Malik, Shafi'i, Hambali and Hanafi [33].

In addition to the above, Quraish Shihab, in a number of quotations, also explained some 
Islamic figures included in the Ahlussunnah group, al Auza'iyah $(88-150 \mathrm{H})$, ats-Tsaury (w.161H), al-Hasan al-Asy'ari (324H-936H), al-Baqillani (403H-101H), Imam al-Ghazali (w. $505 \mathrm{H})$ etc.

Based on the historical view of theology above, the ahlussunnah wal jama'ah is a group that emerged after the birth of the Mu'tazilite understanding, the Ash'ariah and Maturidiah, which are the majority group and strongly hold fast to the sunnah of the Prophet, a group that follows the four Imams of the school and figures, who follows the aqeedah of the Ash'ari sect $[1,2,11]$

\section{Understanding and A Short History of Shia}

The etiology of the word Shi'a in the Arabic dictionary, شيعة, is a single form which means followers. Meanwhile, according to Ali Shomali, the word Shia comes from the Arabic root word sy-ya-'ain in the book Mu'jam Muqayyis al-Laughah, meaning to help and spread [35].

Quraish Shihab explains the word Shi'ah etymologically, which means followers, lovers, defenders, who are aimed at specific ideas, individuals or groups. Shia in the sense of another word is juxtaposed with the word Tasyaiyu, which means obeying / religiously obeying and raising to those who are obeyed with sincerity without doubt [33].

The meaning of the word Shi'ah, according to Gulpaygani[12], has two meanings, namely:

a) Shiite means equality and conformity in matters of belief or deed,

b) Shia means followers, one follows the other, as the Qur'an states that the prophet Ibrahim is the Shia (follower) of the prophet Noah (QS. As-Shaffaat: 83).

Understanding Shi'a in Islamic Encyclopedia (1992), is a sect or ideology that deeply idolizes Ali ibn Abi Talib and his descendants, who became priests of the Shiites. This is in line with the opinion of Muhammad Husain Thabathaba'i, etc, in his book Shi'ite Islam, which defines the Shi'a as one of the streams in Islam which believes that the most entitled to become an Imam of Muslims after the death of the Prophet Muhammad is the Prophet's own family, that is the Ahlulbait, including 'Abbas bin' Abdul Muttalib (uncle of the Prophet SAW), and 'Ali bin Abi Talib (cousin and son-in-law of the Prophet SAW) and their descendants [1, 2, 13].

The understanding of Thabathaba'i, is strengthened by the opinion of Asy-Syahrastani that the Shi'a are a group of people who support Ali ibn Abi Talib, this group believes that Ali ibn Abi Talib is a caliph and imam determined through the texts and the will of the Prophet, openly and implied. This means that Imamat must be from Ali's path and if an Imam does not belong to Ali's lineage, it is tyranny and taqiyah on Ali's side. So Imamat according to Shi'a becomes aqidah or the pillar of religion, not limited to the benefits of religion [14]. This agrees with Abdul Mun'eim Al-Nemr, stating that Shi'a is a school or school of theology in Islam, which rejects the leadership of the first three Sunni caliphs [15].

The understanding of Shi'a from Thabathaba'i and Asy-Syahrastani, as a group that supports and loves Ali bin Abi Talib as Caliph, disagrees with Siradjuddin Abbas, who states 
that it is not only the Shiite group who loves Ali bin Abi Talib, but Ahlul sunnah groups also love Ali even all Muslims also love Ali and his descendants [32].

Conclusion the meaning of the word Shia, as a verb (fi'il) in etymology is follower, defender, help, spread, helper, lover, similarity and conformity to a particular object.

The conclusions of the meaning and understanding of Shia from some of the above opinions vary greatly from various perspectives, but in general the meaning of Shia is a group of Muslims (Muslims) who believe in Ali bin Abi Talib and descendants of the Prophet (ahlul bait) as Caliph / Imam after The Messenger of Allah died, and believed that the next Imamate was a descendant of the Prophet Muhammad. This belief became an aqeedah which became the pillar of religion.

The diversity of understanding and meaning of Shi'a also raises various differences in the views of historians in describing the history of Shi'ism, including; Ibn Khaldun, Ahmad Amin, Ahmad Bin Ya'qub and many other writers. In this paper the authors only limit the three writers who describe the history of birth or the emergence of Shiite groups.

History of the birth of Shi'a according to Ibn Khaldun, the emergence of Shi'a when the Messenger of Allah died, the Ahlulbait held that they were more entitled to lead Muslims, replacing the leadership of the Prophet Muhammad and that the right of Caliphate belonged to Ahlulbait, not to other Quraysh. At that time some of the Prophet's companions supported this view, and when the leadership was not controlled by Ali ibn Abi Talib, they also complained about the incident [16]. This understanding is the same as Dr. Ahmad Amin, who wrote the history of Shi'a in his book Fajr Al-Islam, The emergence of Shi'a was a group of people who argued that after the death of the Prophet Muhammad, the young Ahlul Bayt became the caliph and his successor than others [36].

Opinion that is different from the history of Shi'ism above was stated by Siradjuddin Abbas, who wrote that the emergence of Shi'a around $30 \mathrm{H}$ during the reign of the Caliph Uthman bin Affan. A Jewish priest from Yemen named Abdullah bin Saba 'who converted to Islam, and migrated to Medina. Abdullah bin Saba 'hoped to receive a welcome in Medina because as a great Jewish priest from Yemen who emigrated, but did not get a welcome or appreciation from the people of Medina and Caliph Uthman bin Affan. Eventually he made an anti-Saidina Uthman movement, tore it down and replaced it with Saidina Ali bin Abi Talib. Abdullah bin Saba 'greatly praised Ali bin Abi Thalib and looked down on three other companions of the Prophet [32].

Pizaro Novelan, a journalist and editor of Islampos.com, agrees with Siradjuddin Abbas. Pizaro wrote that in the 20th century, Jews and Shiites had tried to erase the name Abdullah bin Saba, who was considered a fictional figure created by Ahlussunah Wal Jama'ah through the hands of Thaha Hussein. But this is refuted by the writings of the classical Shiite scholars, who acknowledge the existence of Abdullah bin Saba '. The story of Abdullah bin Saba ', written by Sa'ad Al Qummi, Abu Muhammad Hasan ibn Musa An Nubkhty and historian Ahmad al Ya'qubi. In addition to the classical Shi'ite figures, the figure of Abdullah bin Saba 'has been written in full by Dr. Sya'diy Hasyimi in the book titled "Ibn Saba" Haqiatun La Khayal. "In this book explains about Jewish ideology that infiltrated the Shiite sects [37]

Pizaro's opinion is different from the opinion of Quraish Shihab, who gives his arguments with several books. M. Quraish Shihab concluded that the Shiite seed was not sourced from Jewish and Persian teachings (as predicted by the Orientalists and followers), but Shia grew 
normally [33].

According to Muhammad Abu Zahrah, Shi'a was a political school that was first born in Islam. The Shi'ah appeared at the end of Uthman's reign, then grew and developed during Ali's time. The Shiites agreed that Ali was the chosen Caliph of the Prophet and Ali was the foremost among the Companions of the Prophet. The Shi'ites did not behave in the same way in establishing the position of Ali and his descendants, some were extreme and some were moderate. Moderate groups are limited only to prioritizing Ali over all friends, do not disbelieve someone and do not cult Ali to be seen as overcoming all humans [41].

From some of the debates above about the emergence or Shiite seed shows a variety of opinions from various historians, scientists (researchers), classical and contemporary scholars. But in general it can be concluded that the Shiite group emerged after the death of the Prophet Muhammad.

During its development, the Shi'a split into countless groups. Quraish Shihab explained the development of Shiite groups as follows:

1. Shi'a Ghulat

2. Shi'a Ismailiyah

3. Shia Zaidiyah

4. Shia Istna 'Ashariyah (= Imamiyah or Ja'fariyah)

From this large group, several small groups emerged including As-Sabaiyah, AlKhaththabiyah, Al-Ghurabiyah, Al-Qaramithah, Al-Mashuriyah, An-Nushiziyah, AlKayyaliyah, Al-Kaisaniyah, Al-Jarudiyah, As- Sulaimaniyah, Ash-Salalihiyah and so on. The largest and majority groups in Iran, Iraq, Syria, Kuwait, India, Saudi Arabia and the former Soviet Union are the Shi'ite Istna 'Ashariyah [33].

\section{Similarities and Differences}

Sunni and Shiite groups have in common as fellow Muslims. According to Abu Bakar Aceh, that the Sunni and Shiite sect agreed to use the basic legal sources that became the main basis in

Islam are the Qur'an and Sunnah (Aceh, 1980). This opinion is reinforced by Al Habsy, who stated that the similarities between Sunni and Shi'a are fellow Muslims who believe that Islam is sourced from the Qur'an and Hadith [17]. Sunni and Shi'a are united by the verses of the Qur'an which read:

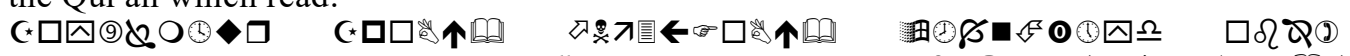
(1) 1 Q $\square$ (9)

"Surely your people are one people and I am your Lord, so worship Me." (Surat alAnbiya [21]: 92)

The difference between the two comes along with the emergence of legal sources after the Koran and al Sunnah, known as Ijma 'and Qiyas, during the Prophet's companions and after the death of the Prophet Muhammad [18]. According to Abu Bakar Aceh (1980), the difference arises in the two schools because of the problem of interpretation of the imams 
who are the reference of the Sunni and Shiite schools. The Imams differed in questions on how to practice the teachings from the main source of Islam, a problem which was a branch of religion (furu'iyah). Factors that influence these differences, due to difficulty understanding the verses of the Koran, life problems that always grow in various forms according to place, time and way of thinking of humans, and differences in the capture of what is heard from the hadiths of the Prophet.

Similarities and differences between Sunni and Shi'a, according to Azyumardi Azra (2017), stated that in reality, between Shi'a and Ahlul Sunnah, there are more similarities than differences. A little difference only concerns things that are not principle. For example, regarding Imamat (leadership) and in matters of fiqhiyah, differences in terms of furu'iyah (twigs), are not the subject. Therefore, Shi'a cannot be called a sect (outside of Islam, it becomes a separate religion).[38]

\section{The Dynamics of Sunni-Shi'ah in The Pre and Post "The Arab Spring"}

Before the Arab Spring, we knew the Iraq-Iran armed war. The Iraq-Iran conflict in the Middle East region represents the conflict of Sunni and Shiite groups. This conflict ended with the overthrow of Saddam Hussein's regime in Iraq (Abidin, 2012).

In 2010 in the territory of the Arab countries, there have been a number of political uprisings. Sidik Jatmika wrote in the journal International Relations, stating that the conditions of the fall of regimes such as in Tunis, Egypt and Libya, following the massive resistance of the people in the country, reflected the crisis of legitimacy and weakness of the authority of many political leaders in the region as well. At that time, the loyalty of many people in Arab countries to their leaders was also a problematic decision when dealing with their primordial affiliations such as Ashabiyah, Wathanniyah, Qaummiyah and the ummah. The Arab Spring is a political movement, which provides lessons that leadership and national character building are not finished and will never end as a process. This phenomenon also emphasizes the importance of the political system to be adaptive to the dynamics of the domestic political situation and the international atmosphere. Failure to adapt to such conditions will result in the fall of the ruling authority [19].

Ahad Sahide in the Kawistara journal, writes that The Arab Spring shows the political dynamics in the Middle East region, especially Arab countries. In early January 2011, marked by the rise of hopes for a better and more democratic political system with the fall of authoritarian leaders, starting from Tunisia namely Zein Al-Abidin Ben Ali (Ben Ali), who spread to Egypt with the overthrow of Hosni Mubarak, then crossed into Libya, with the end of the era of the dictatorship of Moamar Khadaffi (Muammar al-Qaddafi) which had lasted for about 40 years. The Arab Spring is also marked by an increasingly heated conflict between Shiites and Sunnis in line with the hope season. The Arab Spring is a momentum for both streams in Islam to strengthen its influence in politics in the region with efforts to get rid of the others. That happened in Bahrain, Egypt and Syria, which is still in turmoil to this day [20]. 
According to Riza Sihbudi, conflicts between Sunni-Shi'a especially in the Middle East region, have two universal forms. First, conflict between community groups and regimes, both Shiite regimes and Sunni and vice versa. Second, conflicts between countries (regimes) [21].

The first form of conflict can be seen from the war between Sunnis (minorities) and Shiites (majority) in Iraq. According to the United Nations, in April 2013 more than 700 people were killed in Iraq. Religious conflicts between Shiites and Sunnis have occurred and reached their peak in 2006 and 2007.

The second form of conflict can be seen in the Syrian conflict which until now has not been completed. At first the Syrian conflict was internal, but it turned into a conflict of interests between countries because there was a foreign game that had a huge influence. From this conflict, there is a battle between the United States and its allies, which are predominantly Sunni, with China and Russia which are always cooperating with Iran, known as the Shi'ite state. Sunni countries are also behind America, one of them is Saudi Arabia, while Shi'a countries are behind China and Russia. Relations between Saudi Arabia and Iran have always had major problems, both political, strategic, and ideological (Shiite and Sunni). They fight for influence and supremacy in the Middle East and the Gulf. During the Syrian crisis it was clear that Iran supported the Shiite Bashar al-Assad regime, while Saudi Arabia supported the Sunni majority opposition group. Iran's ownership of nuclear is also a problem for Saudi Arabia. Saudi Arabia really does not want its position as the leading primus inter pares (mutalak ruler) among fellow Muslim countries rivaled by Iran [20,22].

From the explanation above illustrates that after the Arab Spring, the dynamics of SunniShi'a relations show mutual influence in the turbulent countries in the Middle East. This means that political conflict is the background of the relationship between Sunnis and Shiites.

\section{Dynamics of Sunni and Shia}

The outbreak of the Shiite revolution (1977-1979) in Iran became one of the expansion of Shiite groups into Indonesia. Most people assume that Iran succeeded in carrying out the "Islamic Revolution", so that it is considered a role model of "Islamic Republic in the world [37].

As'ad Ali, vice chairman of the PBNU wrote an article about the Shiite Movement in Indonesia, in May 2011, stating that the Shi'ites in Indonesia were trying to create the MarjaAl Taqah Institute. A highly centralized religious leadership institution, whose preacher was prominent Shi'a scholars, had full authority for the formation of the Shi'a government and constitution as well as the maktab or askariyah lajnah.

The activities of the Shiite group began to appear at the Ashura memorial, December 2012. The mass media reported the Ashura warning at Puri Garini, Halim Perdana Kusuma Jakarta, which was attended by 8,000 Shiites. In addition to Jakarta, the Ashura commemoration was also carried out in several areas, including the Gedung PramukaSamarinda, in. Sriwijaya- Palembang Women's Building and other areas in Medan, Padang, Bengkulu, Bandung, Yogyakarta, Semarang, Surabaya and other big cities. 
In addition to the religious activities mentioned above, the development of Shi'a is also shown by the establishment of Shi'i educational institutions. The results of Apridar et al's research on Shi'ites in Aceh showed that the development of Shi'as socially in the map of Indonesia's Islamic world, illustrates that Shi'a schools experienced significant growth. The development of Shi'a especially after the 1979 Iranian revolution which developed much earlier than the Sunni school of thought attracted many young Muslims in Aceh. The development of Shiites in Aceh is very rapid compared to the two schools of thought, Sunni and Wahabi [39].

Based on the explanation above, it shows that the Shi'a began to grow and develop in Indonesia rapidly. While the majority of Muslims in Indonesia, including the Ahlussunnah Wal Jama'ah, including those who are members of the NU, Muhammadiyah, Persis, etc. also developed with the activities of preaching. It seems that the Sunnis and Shiites in Indonesia developed in the life of the nation and state, but in their development there were several conflicts between the two groups in several regions.

\subsection{Conflict Sunni-Shia in Indonesia}

The Sunni-Shiite conflict that left one dead, four critics and dozens of houses burned on August 26, 2012, shocked the mass media in Indonesia. Shiite groups were driven out of their hometowns and lived in refugee camps in the Sidoarjo area. On May 21, 2017, a declaration emerged in Surabaya which was attended by various elements of the community, such as the KONTRAS Surabaya, JIAD, AMAN Indonesia, ABI East Java, interfaith groups, as well as Shiite Sampang residents. In the declaration demanded the return of Shiite citizens to Sampang Madura. The declaration also reminded President Joko Widodo's administration to have authority and obligations, to ensure the rights of its citizens where the state is obliged to protect and guarantee the independence of each of its citizens to embrace and practice their beliefs on the basis of the law (Riski, 2017).

According to Lailatul Munawaroh in his thesis, it was written that the Sunni-Syiah conflict in Sampang, Madura did not only occur once, but had occurred from 2006 to 2012. This case had not been resolved despite the reconciliation team formed by the government [23].

Based on Lailatul Munawaroh writings, other researchers and on-line news sources [7, $23,24]$, the following are some examples of cases of the Sunni-Shiite conflict in Indonesia, specialy in Java as sample, in the period 2000-2018, including the following:

\subsubsection{Case in Pasuruan, East Java}

a. YAPI anti-Shi'a demonstration (Islamic boarding school foundation) in Bangil, on December 24, 2006, destroyed 3 houses, 2 prayer rooms.

b. On April 20, 2007, Islamic mass organizations (Peris, Muhammadiyah, Nahdhatul Ulama) calling themselves HAMAS numbered 200 people, led by Habib Assegaf, planning to visit the YAPI Bangil Islamic Boarding School. 
c. On Friday, (01/04/2016) held a demonstration to disperse the event 'Wiladah Sayyidah Fatimah' which was held by the Shiite sect in Bangil, Pasuruan

\subsubsection{Case in Sampang, Madura, East Java}

a. The Shiite group in Karang Gayam Village, Omben District, Sampang Regency, on April 9, 2007, while celebrating the Prophet's Birthday was opposed by the ASWAJA group who dispersed the activity.

b. Sunni groups in Sampang (12/29/2011) set fire to a number of Shiite leader house and mosque facilities in Karang Gayam village. In this incident there were no casualties, but Shiite residents were evacuated to the Sampang Sports Building.

c. Sunni-Shiite conflict (12/26/12) in Omben, Sampang, resulting in the death of one person.

\subsubsection{Case in Bondowoso, East Java}

On April 3, 2016, thousands of Bondowoso Muslims rejected the Shiites. About 3,0005,000 mass representatives from $30 \mathrm{NU}$ pesantren in Bondowoso, the Sunni Ulama Communication Forum (FOKUS), representatives from Muhammadiyah and Al-Irshad elements held a long march hoping that the government would control the Milad Fatimah event and not to curse the Prophet, the family and friends of the Prophet . However, on April 6, 2016, the Shi'ites in Bondowoso continued to hold the Milad Fatimah event with tight guard.

\subsubsection{Case in Batang District, Central Java}

The burning of the Al-Hadi Islamic Boarding School in Brokoh Village on April 14, 2000 , resulted in the destruction of a house, a car belonging to the chairman of the local IJABI (Association of Indonesian Ahlulbait Jamaat), was damaged and a material warehouse was set on fire by a mob.

\subsubsection{Case in Semarang, Central Java}

a. Ashura celebrations conducted by Shi'ites in the city of Semarang, Central Java, Tuesday (11/10/2013), were marked by acts of refusal from members of a number of Islamic mass organizations. So the Shiite version of the Muharram 10th celebration was canceled.

b. On Monday (09/17/2018), hundreds of paramilitaries from representatives of Islamic organizations visited the Shiite headquarters in Layur, North Semarang, Semarang City, Central Java. The Semarang Islamic Community Forum (FUIS) action was carried out as a form of show of force so that they would not hold an Asyuro celebration in Semarang. Based on the example of the case above, in the past eight years, it shows that the Sunni-

Shiite groups are still in conflict in several areas, especially in East Java. 


\subsection{Unifying Efforts and Harmonious Relations between Sunni and Shia in Indonesia}

Some of the efforts to unite Sunnis and Shiites in Indonesia are seen in the following examples written in books and research:

a. Publication of the book, Muhammad Quraish Shihab wrote a book entitled, "Sunnah Syi'ah Bergandengan Tangan! Mungkinkah? (Sunnah Syi'a Hand in Hand! Is it possible?) - Study of the Concepts of Doctrine and Thought. "In this book Quraish Shihab attempts to critically study the concepts of teachings and thoughts between the Sunnah and Shi'a. From this paper, we try to find a common ground between the two religious sects. In this presentation also revealed the possibilities that can be pursued by Sunnis and Shiites to work together in the corridor of unity, Islam.

b. Some scientific writings and research, especially from Islamic scholars, provide alternative conflict resolution (conflict reconciliation) between Sunnis and Shiites, including:

1) Mundiroh Lailatul Munawaroh, "Settlement of Sunni-Shiite Conflicts in Sampang Madura," (Thesis S2 of Religion and Philosophy Study Program, Postgraduate of Sunan Kalijaga State Islamic University, Yogyakarta, 2014). The results of this study provide an alternative reconciliation of Sunni-Shiite conflict in Madura by involving the government.

2) Doddy Iskandar, "Communal Peace and the Role of Sunni and Shiite Civil Society in Pemalang, Central Java," (Thesis. Faculty of Social and Political Sciences, Syarif Hidayatullah State Islamic University, Jakarta, 2016). This study looks for factors that cause positive interactions and cooperation between Sunnis and Shiites.

3) Ibnu Hasan Muchtar, "Shi'a in Tasikmalaya: Management of Harmony with Other Communities." Harmoni Journal vol 16.1 (2017): 109-129. In this article shows a harmonious relationship between Shiites and non-Muslims. This is indicated by the absence of conflict between the two groups. Some Shi'ite figures associated with IJABI (Association of Indonesian Ahlul Bayt Jamaat) and community and religious leaders in Tasikmalaya, know each other personally. There is good collaboration between community members in many socio-cultural events such as mutual cooperation (mutual cooperation), religious festival celebrations, national days at the grassroots level. But there was resistance in the form of demonstrations and declarations of ANNAS (Anti-Shi'a National Alliance). However, this is largely due to the use of social media.

4) Anik Farida, "The Response of Islamic Mass Organizations to Shiites in Bandung, West Java." Penamas Journal vol. 27.2 (2017): 159-176. In this journal write the results of research on the response of Islamic social organizations (Ormas) to the Shiites in Bandung, West Java. The conclusion from this study shows that the response to the existence of Shi'ites in West Java can be grouped into two, which were represented by two CSOs, namely the Indonesian Ulama Forum (FUUI) and the Indonesian Sunni-Shi'a Ukhuwah Council (Muhsin). FUUI rejects Shi'a with 
theological purification argument, while Muhsin accepts the existence of Shi'a, without having to accept interpretations of Islamic teachings from Shiite Muslims. This is based on arguments for safeguarding universal values, such as pluralism, tolerance, and citizenship rights.

5) Ali Muhtarom, "A Sunni-Shiite Crossing Point." Saintifika Islamica: Journal of Islamic Studies vol 2.02 (2017): 61-72. This article describes the Sunni-Shi'a differences only on the question of interpretation of the Imams who are the reference of these two schools. In the context of Sunni and Shi'a the ulama of the school is the link of the teacher and student relationship as Imam Hanafi and Imam Malik teach on Imam Ja'far Sadiq. The imams differed in matters on how to practice the teachings of the main sources of Islam in matters of a religious nature (furu'iyah). Efforts to find common ground between Sunnis and Shi'ites have been established for a long time between the scholars of the Sunni and Shi'ite schools of Islam, conducted between Imam Ja'far Sadiq and Imam Hanafi, Imam Malik and the pattern of relationships between the students of the Imams. In the modern context, efforts to bring together the two Sunni and Shiite schools of thought were also initiated by the Egyptian ulama and several other Islamic scholars as well as the formation of "Darut Taqrib bainal Mazahibil Islamiyah" and the creation of the magazine "Risaltul Islam". With the aim of establishing relationships and spreading the idea of harmony among scholars in the Islamic world.

c. Activities on Campus

After the Iranian Revolution (1977-1979) around the 1980s, many Indonesian students were interested in learning Shiite thoughts, because the Shiites offered rational and critical ways of thinking. The development of the number of Iranian scholars coming to Indonesia conducting discussions / studies, even Iranian Corner has been established in 12 Islamic and public campuses [37]. Translations of books on the thoughts of Shi'ite figures are also widely published and are read by students and social comunity. This means more open dialogue between Shi'ites (Iranian Scholar) and Sunnis, represented by intellectuals on Islamic, General campuses and social comunity [25].

These efforts are expected to be a trigger for openness to be able to understand each other between Sunni and Shiite groups, as well as looking for alternatives to solving problems or reconciling conflicts between the two parties, especially those who live together in Indonesia.

\section{Understanding the Psychological of The Sunni and Shia Group}

According to Nazarudin Umar (2015), describing psychological minority groups, that individuals or anyone who is in a minority group often subconsciously feel less confident to express their full potential, because there is a feeling of feeling small in the middle of a large number. Consciously or unconsciously, individuals who are in a minority group feel that they always feel under the shadow of the majority group, often feeling themselves inadequate to access as fully as what the majority group can do. Likewise with the psychological majority 
group, Nasaruddin also explained that someone who is in the majority group often subconsciously feels more confident, sometimes even over confident, thus forgetting to control themselves.

Sunni-Shi'a relations that occur in Indonesia show the social interaction of majority

(Sunni) and minority (Shiite) groups. The quality of the relationship between the two shows a lack of conformity between members in a community group, loss of organic intimacy (=mutual understanding, empathic, loving, affection) in social relations, no continuity of experience between groups, unstable and rapidly changing. This is a characteristic of social disorganization [40]. The loss of organic initimitas from social relations will form extreme individualistic patterns and selfish desires (group), relationships are broken, so that group members will experience frustration due to the unfulfillment of human personal needs.

Based on conflict data that has been presented previously, it shows that the victims, both souls, possessions and psychological trauma are minority groups - Shi'ites. While the majority-Sunni group, feels in a position that is more confident when dealing with Shiite groups in Indonesia, has even committed acts of violence resulting in fatalities.

The cause of the emergence of acts of violence in social interaction between Majority and Minority groups in the perspective of Social Psychology, was investigated by Saloom (2013).

Saloom's research, entitled, "Majority-Minority Social Psychology: Testing the Effects of Social Identity, Orientation, Perception of Threats in Support of Violence," explains that a person who identifies himself strongly in a particular religious group or school and has a orientation to group or social dominance (Social Dominance Orientation) which is high and has a perception of certain threats to the group and its schools, it tends to provide support for acts of violence against groups that threaten it $[26,27]$.

The cause of conflict between groups can also be caused by social illusions that cause prejudice, stereotyping, fanaticism, etc $[28,29]$. The Sunni-Shi'a case begins with fanaticism towards their leader or Imam, then stereotypes and prejudices emerge, which will shape discrimination. This continues until it becomes a conflict and an act of violence.

\section{Sunni-Shia in Indonesia: United in The Differences}

Sunni-Shiite has some differences that are furu'iyah, but have a very fundamental similarity, namely recognizing Islam that comes from the Qur'an and the Hadith (Sunnah Rasulullah). That is, it is still very possible to live together in peace, becoming a unity as Muslims living in the territory of Indonesia, which is famous for its diversity.

Several attempts to unite Sunni-Shi'a have been made, both in the form of writing, research and joint social action in several areas. Including one of them is the findings of the research of Saloom (2013), which shows that the causative factor that contributes the most is the perception of threat $(=29.3 \%)$, while the SDO (Social Dominance Orientation) factor is only $3.3 \%$ and the Social Identification factor is very small $(<1 \%)$. This means, perception becomes a dominant factor in supporting acts of violence [26].

According to the authors, based on the results of Saloom's research (2013), efforts that 
can be made to unite the two groups are by changing perceptions. The sensing process and the thought process of a stimulus will affect one's learning ability in understanding an object and even the social reality in the environment $[28,30,31]$. The change in perception referred to in this case is social perception, which has many factors in influencing one's understanding of social reality. Changed in social perception will minimize conflicts caused by social illusions including prejudice, stereotyping, fanaticism etc [28, 29].

In addition to changing perceptions, it is necessary to increase activities that foster understanding and understanding, which reflect togetherness as Muslims in one country, Indonesia. The forms of business making changes include:

a. Providing insight or introduction about Islamic thought (Theology) at the senior secondary level through tertiary level.

b. Publication the dialogical books between the two parties that lead to unity in difference.

c. Dialogue between leaders and scholars from both parties.

d. Reducing the over-convident nature of majority-Sunni groups by reminding not to be prejudiced according to Islamic teachings in the QS. Hujurat: 12.

e. Increasing scientific writings and research for change the people perception and to minimize the social illlusion.

f. Student and teacher exchange between two groups.

g. Social activities that can be initiated by both parties or the State (as the party which is obliged to guarantee the life and freedom of religion), etc.

These efforts to minimize and even eliminate social illusions, which include prejudice, stereotype, fanaticism, favoritism, etc., as a cause of social conflict.

\section{Conclusions}

Based on the results of the explanation above, it can be concluded as follows:

a. The disharmony between Sunni and Shi'ah began in the post-Rasulullah SAW era, and has continued to this day.

b. Divisions occur starting from the political aspect (power struggle) and differences in furu'iyah issues that have implications for worship and life in the state.

c. Sunni-Shi'a have differences and similarities, while reflecting the potential for conflict or unity.

d. The dynamics of Sunni-Shiite relations in the Middle East tend to conflict to show their respective effects, although some scholars have tried to unite in scientific activities, publishing journals and books.

e. The dynamics of Sunni-Shi'a relations in Indonesia are marked by social conflicts in several regions, especially Java, but there are also many efforts to unite the two parties.

f. Efforts to unite the differences between Sunni-Shia in psychological review is to make changes in social perception to minimize social conflict caused by social illusions (= prejudice, stereotype, fanaticism, etc.). 
Thus this paper was made to be able to understand the relationship, understand the differences and similarities between the two groups, Sunni and Shia. Shiite groups in Indonesia show significant development and the possibility of reconciliation with Sunni groups is starting to meet.

\section{References}

[1] A. Sahidin, "Memahami Sunni dan Syiah: Sejarah, Politik, dan Ikhtilaf," dalam Jurnal Maarif, vol. 10, pp. 31-51, 2015.

[2] S. Mulyono, "Pergolakan Teologi Syiah-Sunni: Membedah Potensi Integrasi dan Disintegrasi," Ulumuna, vol. 16, pp. 245-278, 2012.

[3] J. Harney, "How Do Sunni and Shia Islam Differ?," New York Times, vol. 4, 2016.

[4] M. Abou-Zahab, "The Sunni-Shia conflict in Jhang (Pakistan)," in Lived Islam in South Asia, ed: Routledge, 2017, pp. 161-174.

[5] A. Siegel, Sectarian Twitter Wars: Sunni-Shia Conflict and Cooperation in the Digital Age vol. 20: Carnegie Endowment for International Peace, 2015.

[6] N. Gonzalez, The Sunni-Shia conflict: understanding sectarian violence in the Middle East: Nortia Media Ltd, 2013.

[7] M. A. Isya, "Pendidikan dan Konflik (Potret Konflik Sunni-Syiah dan Imbasnya Terhadap Pendidikan di Bangil Kabupaten Pasuruan)," Progressa: Journal of Islamic Religious Instruction, vol. 2, pp. 13-14, 2018.

[8] V. Nasr, "The Shia Revival," Military Review, vol. 87, p. 9, 2007.

[9] I. Manzur, "Lisān al-‘Arab," ed: Beirut: Dār al-Sadr, 1989.

[10] N. Yuslem, Ulumul hadis, Jakarta: Mutiara Sumber Widya, 2001.

[11] F. Saleh, Teologi Pembaruan: Pergeseran Wacana Islami Sunni di Indonesia abad XX: Serambi Ilmu Semesta, 2004.

[12] A. R. Gulpaygani, "Kalam Islam Kajian Teologi dan Isu-Isu Kemazhaban," Dialih bahasakan oleh Muhammad Jawad Bafaqih. Jakarta: Nur Al-Huda, 2014.

[13] M. H. Thabathaba'i, "Islam Syi 'ah, terj," Djohan Effendy. Jakarta: Grafitipers, 1989.

[14] M. b. A. K. Asy-Syahrastani and A. al-Karim, "Al-Milal wa an-Nihal," Diterjemahkan oleh Asywadie Syukur. Edisi lengkap, Surabaya: PT Bina Ilmu. t. Th, 1961.

[15] A. M. e. Al-Nemr, "Sejarah dan Dokumen-dokumen Syi'ah," ed: Terj. Yayasan Alumni Timur Tengah, Tanpa Penerbit, 1988.

[16] Z. Khudhairi, "Falsafah al Tarikh 'Inda Ibnu Khaldun," ed: Terj. Ahmad Rofi'Usmani. Bandung: Pustaka, 1987.

[17] H. Alhabsyi, Sunnah syi'ah dalam dialog: antara mahasiswa UGM dan UII Yogya dengan Ustadz Husein Al-Habsyi: Yayasan Ats-Tsaqalain, 1991.

[18] J. R. Krull, Islam-Sunni Vs. Shia: What's the Issue?: Allen County Public Library, 2012.

[19] S. Jatmika, "The Arab Spring 2010: Puncak Gunung Es Krisis Politik di Kawasan Timur Tengah," Jurnal Hubungan Internasional, vol. 2, pp. 157-166, 2015.

[20] A. Sahide, "Konflik Syi'ah-Sunni Pasca-The Arab Spring," Jurnal Kawistara, vol. 3, 2013.

[21] M. R. Sihbudi, Bara Timur Tengah: Islam, dunia Arab, Iran: Mizan, 1991.

[22] R. Murtadha and M. Mutawali, "Arab Sunni Dan Iran Syi'ah Kontemporer: Konflik Atau Persaingan?," 2017.

[23] M. L. Monawaroh, "Penyelesaian Konflik Sunni-Syiah di Sampang Madura," Tesis Pasca 
Sarjana UIN SunanKalijaga. Yogyakarta: Dokumen Tidak Diterbitkan, 2014.

[24] M. Rizak, "Pola komunikasi antarbudaya antara masyarakat Syiah Nuruts Tsaqolain dan masyarakat Sunni Semarang," UIN Walisongo Semarang, 2018.

[25] A. Santoso, "Pola Interaksi Sosial Pengikut Syiah Dengan Pengikut Wahabi Di Kawasan Pejaten Jakarta Selatan," 2007.

[26] G. Saloom, "Psikologi Sosial Mayoritas-Minoritas: Menguji Pengaruh Identitas Sosial, Orientasi Dominasi Sosial, Persepsi Keterancaman Terhadap Dukungan Atas Kekerasan," 2013.

[27] G. Saloom, "Akulturasi Islam dan Nilai lokal Dalam Perspektif Psikologi," KALAM,vol. 10, pp. 1-18, 2016.

[28] S. W. Sarwono, "Pengantar Psikologi Umum," Jakarta: Rajawali Pers, 2010.

[29] S. W. Sarwono, "Psikologi Sosial Kelompok dan Terapan," Jakarta: PT Balai Pustaka, 1999.

[30] A. Bandura, "Social-learning theory of identificatory processes," Handbook of socialization theory and research, vol. 213, p. 262, 1969.

[31] A. Bandura and R. H. Walters, Social learning theory vol. 1: Prentice-hall Englewood Cliffs, NJ, 1977.

[32] Abbas, S, I'tiqod Ahlussunnah Wal Jama'ah. Pustaka Tarbiyah Baru. Jakarta, 2018.

[33] Shihab, M. Q, "Sunnah Syiah Bergandengan Tangan! Mungkinkah? - Kajian Atas Konsep Ajaran dan Pemikiran," Tangerang: Lentera Hati, 2014.

[34] Nasution, H., "Teologi Islam-Aliran-aliran Sejarah Analisa Perbandingan," Jakarta: Universitas Indonesia Press, 2015.

[35] Shomali, M. A, “Cakrawala Syi’ah”, Jakarta: Nur Al-Huda, 2012.

[36] Amin, A, "Fajr Al-Islam”, Dar-Kitab Al-“Arabi, Beirut, 1969.

[37] Pizaro, M.N.T., “Zionis \& Syiah Bersatu Hantam Islam,” Tangerang: Arrahman, 2013.

[38] Azra, A., "Pandangan Akademis Tentang Syiah(1)", Misykat.Net. Publikasi: 25 Jan 2017 @ 19:02 http://misykat.net/article/156551/azyumardi-azra-pandangan-akademis- tentang-syiah1.html

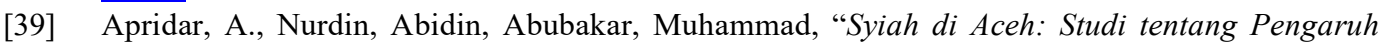
Syiah dalam tradisi Keislaman-Kelilmuan dan Pemetaan Gerakan Sosial Keagamaan." Jurnal KONFRONTASI, Vol (2). pp. 106-126, 2016.

[40] Kartono,K., "Patologi Sosial, Jilid 1,” Jakarta: Rajawali Press, 2009.

[41] Zahrah, M. A, “Aliran Politik dan Aqidah dalam Islam (terjemahan),“ Jakarta: Gaya Media Pratama, 2011.

[42] Kompas. 2013. Dari Riyadh ke Tel Aviv. Berita: Edisi 11 Desember 2013. "Kronologi Penyerangan Warga Syi'ah di Sampang." Nasional. Tempo.Com. Senin, 27 Agustus 2012. https://nasional.tempo.co/read/425697/kronologi-penyerangan-warga-syiah-di-sampang.

[43] "Ormas Islam Datangi Markas Syiah di Semarang," dalam Hidayatullah.Com,18/10/2018 Rizki, Petrus. 2017. "Lima Tahun Terusir dari Kampung Halaman, Pengungsi Syiah Sampang Berharap Negara Hadir." Berita. VOA-Indonesia. 22/03/2017, https://www.voaindonesia.com/a/lima-tahunterusir-dari-kampung-halaman-pengungsi-syiah-sampang-berharap-negra-hadir/3776761.html.

[44] Umar, N. 2015. Psikologi Mayoritas Minoritas. Inilah.com. 24 Januari 2015. https://m.inilah.com/ news/detail/2171433/psikologi-mayoritas-minoritas

[45] Wahet, A. 2016. "Bondowoso Jatim, Umat Islam Diresahkan Syiah yang Nekat Gelar Acara." Nahimunkar.Com, 9 April 2016.

[46] Wahet, A. 2016. "Gabungan Ormas Islam di Bondowoso Tolak Milad Fatimah." Suarajatimpost.com, 3 April 2016. 